\title{
Post-feminism: the individumanism
}

\begin{abstract}
Being "woman" is not all that a person is. It says very little of the individual trajectory. The woman is plural: women. They only exist in the particular form that encloses them. You cannot compare two women or even two men. They are different stories. What should be taken into account is not a matter of gender, but a matter of choices, personal efforts, and individual capacities and so on. This, on the other hand, does not imply the defense of an extreme individualization, but the conviction that this process is almost invariably a humanization of relations. The social feeling of recognition of our human condition. That is, the more we strive for the recognition of our individuality, the more we amplify the dynamics of mutual consideration. Thus, promoting a spiral of recognition among people and, with it, a concrete humanism. What is at issue is the individuality - that distinguishes us from the others -and our humanity-that unites us. Just by operating within these two categories, can we overcome false social prejudices and move towards equality that is not composed of homogeneities but differences that recognize each other as human between the particular and the universal? Exceeding stereotypical intermediate categories: black; women; Poor; Rich; Whites; Bourgeois; workers; Class and so on
\end{abstract}

Keywords: individumanism, black, women, poor, Rich, whites, bourgeois, workers, human, people, amplify
Volume 2 Issue 6 - 2018

Isabelle Anchieta

Department of Sociology, University of São Paulo (USP), Brazil

Correspondence: Isabelle Anchieta, Department of Sociology, University of São Paulo (USP),Via Solaris 62I CD Quintas do Sol, Brazil,Tel 3199923|3 |2, Email isabelleanchieta@gmail.com

Received: August 10, 2017 | Published: December 28, 2018

\section{Introduction}

Such classifications do not help us to resolve the conflict and are more likely to reinforce stereotypes than to break them. Feeding closed collective identities and revanchism. It would be necessary to go beyond such social markers of differences in order to analyze simultaneously more individualizing and universal criteria, in which people can attain their concrete universality what I have called "individumanism"-at the conclusion of my doctoral thesis "Images of Women in the Modern West". In the very sense of understanding that individual is falling short and bey $\mathrm{d}$ of his sex. Morphological, physical, and biological differences (even though there exist) say little about each person. What defines us as humans is exactly our ability to be beyondbiology. Even by manipulating it, reinventing our physical limits. A being who writes, do complex accounts, builds bridges, creates laws, writes poems, or creates works of art cannot be judged simply by its morphological characteristics. In the same sense defined by the sociologist, Judith Butler ${ }^{1}$ when she affirms that being a woman or a man "is not all that someone is." There is in all human creation a kind of necessary transcendence, capable of making its work communicate with others-regardless of gender, ethnicity and color. Is in this sense that to emancipate, woman must become a person. Becoming a person implies walking more in search of humanism than feminism. Such a perspective ends up stretching the path, rather than diminishing it. Because it cannot get rid of the reiteration of the idea of woman. An unsolvable contradiction in which feminists end up "reinforcing the kind of thinking they wanted to fight." In my view, the full goal of feminism will only take place in the dissolution of the idea of women in favor of the idea of the human being. An idea that would bring practical consequences to the social arrangements, promoting an extended solidarity.

\section{Is it the end of the binary model?}

It is a social fact that until the first half of the twentieth century the binary model was foundational (and sometimes still is) active in Western social organization. The idea of woman and man conditioned lives, roles and social functions. Being the debate promoted by feminists and homosexuals around the denaturing of the sexes, the main cause of their growing destabilization. A struggle for recognition that gradually undermines the hierarchical differences between the sexes denouncing their cultural and artificial support through so-called gender research (in the social sciences and in the field of biology). One of the pioneers will be the American anthropologist Margareth Mead. During the 1930s and 1940s, her researches and its repercussion will be central to this denaturalization of the differences between men and women through a scientific argument. Mead investigates three tribes in New Guinea. The Arapesh, the Mundugumor and Tchambuli. In this last one, she surprises with the behavior between the sexes. The women were the hunters and possessed more power and the men more passive and domestic, dedicated to the care of the children. $\mathrm{He}$ then concludes that "human nature is almost incredibly malleable, responding accurately and differently to cultural conditions." More than just a nature, we are dealing with a gender performance, as sociologist Erving Goffman ${ }^{2}$ has also shown in his research on Gender and Propaganda. Analyzing gestures, clothes and functions in the images, the sociologist comes to a similar conclusion that of Margaret Mead when she states that "if there is a human nature it consists in the ability to learn to predict and read representations of femininity and masculinity and the will to adhere to these representations".

The philosopher Judith Butler goes even further, stating that "there is no gender identity behind the gender; this identity is performativity constituted, by the very expressions taken as its results". For the philosopher, the woman will always be a process, a becoming. Denying both a gender identity and even the idea of a substantial, sexed being. Butler also questions the very place of feminism that builds and reaffirms a reifying category of woman, "even when construction is constructed for emancipatory purposes." In the very sense that feminism failed to unleash the reiteration of the idea of women. For if the whole feminist struggle was fundamentally to denaturalize the differences between the sexes, it does not make sense on the other hand to reinforce this identity. ${ }^{3}$ 
Such social scientists are interested not only in revealing gender performances but also in demystifying the idea of women's intellectual inferiority. A global survey conducted in 2012 by US researcher James Flynn in Europe, the United States, Australia, New Zealand and Argentina found that both sexes improved their IQ test performance over the past 100 years, but women improved at a faster rate. ${ }^{4,5}$ Confirming the hypothesis that it is more of a cultural and behavioral issue-in the case of women's access to education- than a natural characteristic intrinsic to the sexes. This is the theme that goes some way to Beauvoir's Second Sex, trying to explain why there are not "great" women in the field of science, art, philosophy and literature throughout history. She asks: The historical fact cannot be considered as defining an eternal truth; it translates only a situation, which manifests itself precisely as historical because it is changing. How could women have never had genius, when all the possibility of performing a masterpiece-or even a work simply-was refused Todorov. $^{6}$

This change foreseen by Beauvoir Simone ${ }^{7}$ will be possible "when it is finally possible for every human being to place his pride beyond sexual differentiation, in the difficult glory of his free existence, can the woman-and only then- confuse her problems, her doubts and her hopes with of the humanity". For the author "while she has yet to strive to become a human being, she cannot be a creator". In this sense, 'post-gender' (or the crisis of gender studies) is equally productive in the debate in question, to the extent as it proves that to delegitimize classifications and social stereotypes it is necessary to enlarge the frame and not return covertly to the same place inside out. More than feeding an endless war without winners, the important thing is to compose a new place of identification outside this binary system in favor of an enlarged frame that unites and pacifies, without homogenizing. Humanity consists of individuals: the individumano.

\section{Acknowledgments}

None.

\section{Conflicts of interest}

The author declares that there are no conflicts of interest.

\section{References}

1. Butler Judith. Gender Problems. RJ: Civilização Brasileira; 2014. 236 p.

2. Goffman Erving. Gender advertisements. New York: Harper Torchbooks; 1976. $100 \mathrm{p}$.

3. Elias Norbert. The individual society. Rio de Janeiro: Zahar; 1994. 3 p.

4. Norbert Elias. The civilization process, v. 2: Formação do Estado e civilização. Rio de Janeiro: Zahar, 1993. 258 p.

5. Norbert Elias. The insidersand outsiders: sociologia das relações de poder a partir de uma pequena comunidade. Rio de Janeiro: Zahar, 2000. $230 \mathrm{p}$.

6. Todorov Tzetan. The life together. São Paulo: Papirus; 1996. 124 p.

7. Beauvoir Simone. The Second Sex. Rio de janeiro: Nova Fronteira; 2009. $873 \mathrm{p}$. 